A. V. Timoshenko, L. K. Gerasimova.

L. l. Kolupaeva, S. N. Cherenkevich

\title{
MANNOSE-SPECIFIC INTERCELLULAR AGGREGATION OF RAT THYMOCYTES AND ESCHERICHIA COLI CELLS TRIGGERED BY TEMPERATURE
}

\begin{abstract}
$D$-mannose was shown to induce disaggregation of rat thymocytes and $E$. coli AB1157 cells at any stage of the process. Mannose-specific aggregation of thymocytes and $E$. coli was inhibited by heating as opposed to concanavalin A-induced thymocyte aggregation. The process was completely reversible at the rapid temperature changes, indi. cating its membrane not intracellular mechanism. Taken together, the results demonstrate that mannose-specific intercellular contacts can be affected differently by temperature.
\end{abstract}

Introduction. Results of recent research emphasize that a notable part of intercellular contacts are based on the protein-carbohydrate interaction $[1,2\}$. Bacterial cells can effectively interact with animal cclls in adincsion and intercellular aggregation reactions $[3,4]$. The mechanisms of these processes are being studied intensively since they are the basis of the development of various bacterial infections [5]. It has been shown that $E$. coli cells bearing type 1 fimbrial lectin bind to mannose-containing glycoligands on the surface of macrophages and neutrophils [6]. Recently, we have found that $E$. coli $A B 1157$ cells also induce aggregation of rat thymocytes, while heat-inactivated bacterial cells lose this activity [7]. Earlier, heating was shown to affect lectin-dependent interactions in cellular and model (liposomes) systems $[8,9]$. The mannose-specific intercellular aggregation of rat thymocytes and $E$. coli may be used to model lectin-carbohydrate contacts between animal and bacterial cils in suspensions, because, in comparison with phagocytes, thymocytes hasc little unspecific adhesion to a majority of surfaces.

In the present study we investigated the effect of the temperature provoking structural and morphological changes in the cell plasma membrane on the rat thymocyte aggregation induced by $E$. coli $\Lambda \mathrm{B} 1157$ and mannose-binding lectin concanavalin $A$ (Con-A). Our rosults show that in contrast to Con-A-induced aggregation, the mannose-specific interes:lular aggregation of rat thymocytes and $E$. coli is triggered by the rapid temperature change and occurs at the another iemperature range. (USA).

Experimental. D-mannose and Con-A were obtained from «Sigma»

The thymocytes were isolated from the thymus gland of male Wistar strain rats, 6-8 weeks of age, and suspended in phosphate-buffered saline (PBS), $\mathrm{pH}$ 7.3, containing $137 \mathrm{mM} \mathrm{NaCl}, 2.7 \mathrm{mM} \mathrm{KCl,} 5 \mathrm{mM}$

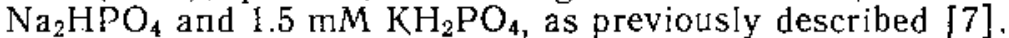

$E$. coli AB1157 cells were cultured by the standard inethod [10]. Briefly, the bacteria were grown overnight at $37^{\circ} \mathrm{C}$ in a beef-extract brath and washed two times with PBS before use.

The aggregation of rat thymocytes induced by $E$. coli as weli as by Con-A was measured by changes in light transmission at $590 \mathrm{~nm}$ of coll suspensions [7], which were kept at a constant temperature and with continuous stirring.

(C) A. V. Timoshenko, L. K. Gerasimova, L. I. Kolupaeva, S. N. Cherenkevich, 1994 
Results and discussion. The rat thymocytes aggregated in the presence of $E$. coli $\mathrm{AB} 1157$ at room temperature (fig. 1). The order in which cells were added played no role in the results, the intercellular aggregates were microscopically visible. To test the stability of cell aggregates the gaptenic sugar D-mannose was added at various time points of the aggregation process. Independent from addition time, D-mannose in concentration of $45 \mathrm{mM}$ elicited the complete disaggregation of cells (fig. 1).
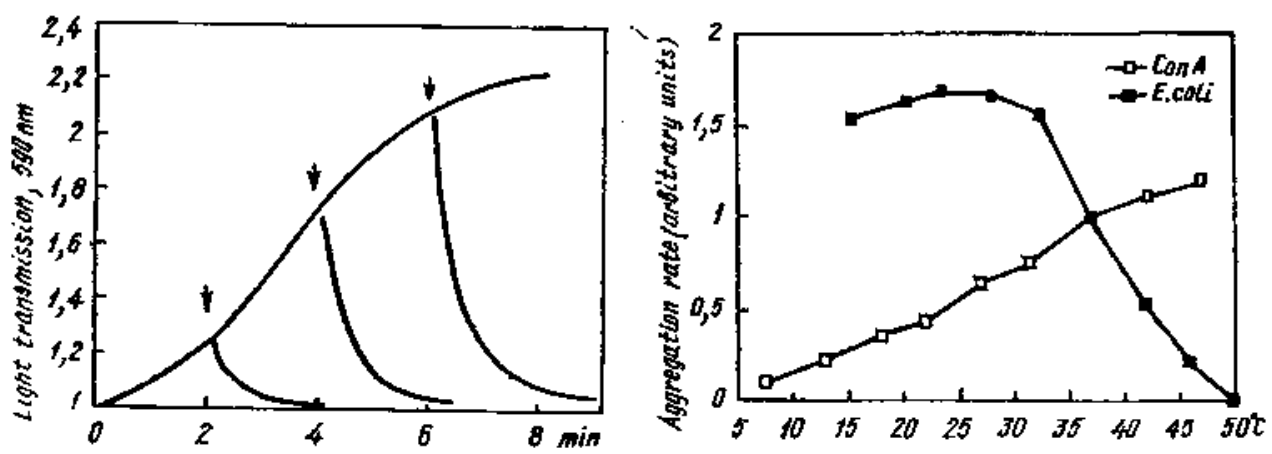

Fig. 1. Aggregation of rat thymocytes by E. coli. E. coli cells $\left(1.5-10^{\mathrm{B}} / \mathrm{ml}\right)$ were added at time zero to thymocyte suspension $\left(7 \cdot 10^{8} / \mathrm{ml}\right)$ in PBS at $20^{\circ} \mathrm{C}$; D-mantiose (45 mM) was added after the bacteria as indicated by the arrows. The traces are representative of at least three experiments

Fig. 2. Effect of temperature on rat thymocyte aggregation induced by $E$. coli and Con-A. E. coli cells $\left(1.3 \cdot 10^{8} / \mathrm{ml}\right)$ or Con-A $(50 \mu \mathrm{g} / \mathrm{ml})$ were added to rat thymocyte suspension $\left(4.5 \cdot 10^{6} / \mathrm{ml}\right)$ in PBS kept at the indicated temperature. Aggregation rate was calculated as an incline of tangent to bend point of trace. The illustrated data are representative of three experiments

Earlier, other sugars (D-glucose, D-galactose, lactose, D-maltose, L-rhamnose et al.) were found to be inactive to affect the intercellular aggregation [7]. The high carbohydrate specificity of this reaction prompted us to compare it with another mannose-specific aggregation of rat thymocytes induced by Con-A.

Fig. 2 illustrates the effect of temperature on the rat thymocyte aggrecration induced by $E$. coli in comparison with those induced by mannosc-binding lectin Con-A. It was observed that the rate of thymocyte and $E$. coli intercellular aggregation decreased with the temperature increase. On the contrary, heating raised the rate of Con-A-induced thymocyte aggregation (fig. 2). Thus, mannose-specific contacts of cell surfaces formed by bacterial and plant lectins display different sensitivity to temperature.

Since at $50^{\circ} \mathrm{C}$ rat thymocytes and $E$. coli did not interact (fig. 2), we hypothesized that high temperature might destroy intercellular confacts due to the reversible heat-induced structural changes of respective plasma membrane components. This supposition was proven by special experiments, when the temperature of samples was changed rapidly (for $15-25 \mathrm{~s})$ during the process of aggregation. Indeed, the intercellular aggregation of rat thymocytes and $E$. coli proceeding at $16^{\circ} \mathrm{C}$ was stopped with the rapid jump in the temperature of the sample to $50^{\circ} \mathrm{C}$, thus the cell aggregation process was replaced by disaggregation (fig. 3). Furthermore, it was reversible with the following rapid decrease in temperature to $16^{\circ} \mathrm{C}$ (fig. 3). At the same time, Con-A-induced aggregation of thymocyles could be stopped by rapid fall in temperature without cell disaggregation (not illustrated).

The results of the study reported here show that intercellular contacts between $E$. coli AB 157 and rat thymocytes are based on the mannose-specific interaction of respective surface structures. Apparently, the type 1 imbrial lectin of bacterial cells takes part in this reaction as well as in process of lectinophagocytosis of the bacteria by phagocyles [6]. 
Since the lection is expressed by many virulent strains of $E$, coli [11, 12], the possibility of forming intercellular contacts of bacterial and lymphoid cells may be significant for the development of the local immune response.

To the best of our knowledge, the results first demonstrate that mannose-specific intercellular coritacts can be affected differently by temperature. Thus, heating stimulates rat thymocyte bridging by exogenous lectin Con-A apparently due to clasterization of mannose-containing plasilla membrane glycoligands. However, the mannose-dependent interacíon of thymocytes with $E$. coli via bacterial lectin is blocked by heating. In this

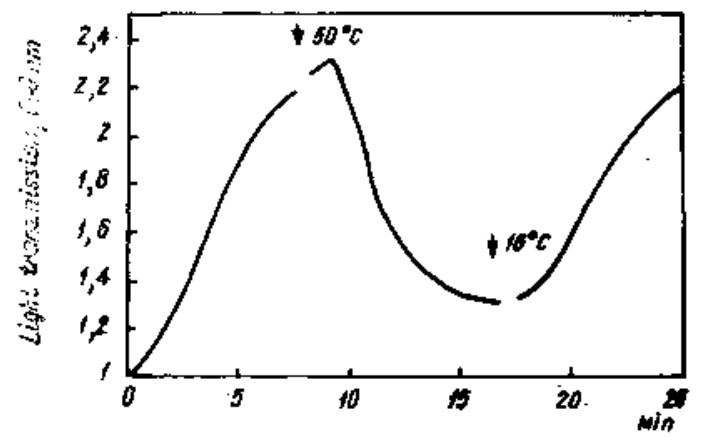

Fig. 3. Aggregation and disaggregatit) of rat thymocytes induced $b ; E$. coli at the rapid temperature changes. E. coll $\left(1.3 \cdot 10^{\mathrm{z}} / \mathrm{mI}\right)$ were added to rat thymocytes $\left(5 \cdot 10^{6} / \mathrm{ml}\right)$ in PBS at $16{ }^{\circ} \mathrm{C}$. Where indicated by the arrows, the temperature of sample was rapidly ihanged and recording was continnted. The traces are representative of it least three experiments

case we deal with the direct contacts of cellular surfaces without a connecting intermediate like exogenous Con- $A$. This phenomenon is an inportant example of mannose-specific biorecognition triggered by tesuperature. Remarkably the fact that one can «switch on» and «switch off» this process (fig. 3) indicates membrane involvement but not ithtracellular mechanisms. High complementary of cell contacting surfaces is sip posedily necessary to form the stable intercellular contacts, whicl are destroyed easily at the temperature change. This is in keeping with the thrombocyte aggregation sensitivity to temperature due to the morphological changes of the cell surface as studied by Samal et a!. [13]. A structural state of mannose-specific [imbrial lectin of $E$. coli is also important since it has been shown to affect cells only in immobjazed form [14].

Futhermore, hydrophobicity of bacterial cells [15] maly inso ilay a role in their adhesion to thymocyies at lower temperature. Further experiments are required to elucidate the mechanisms of the temperabre. dependent biorecognition of bacteria and mammalian cells.

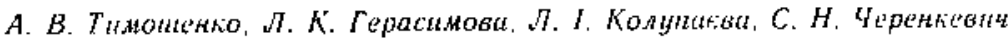

\section{ВПЛИВ ТЕМПЕРАТУРИ}

НА МАНОЗОСПЕЦИФІЧНУ АГРЕГАЦІЮ ТИМОЦИТІВ ЩУРІВ

I БАКТЕРIAЛЬНИХ КЛITИН ESCHERICHIA COLI

P e 3 to $\mathrm{m}$ e

Ветановлено, що D-маноза викликає дезагрегацію тимоцитів щурів і бактеріальних клітнн $E$. coli 1157 на будь-якій стадії процесу міжклітннноі агрегації. Маиюзоспецифічна агрегація тимоцитів i $E$. coli прнгінувалася із підвищенням температури на противагу прискоренню агрегації тимоцитів, викликаної кокканаваліном А. Процес міжклітннної агрегаціі тнмоцитів і бактеріальних клітин був повністю зворотнім за різкої зміни температурн, внаслідок чого натрівання суспензії до $50^{\circ} \mathrm{C}$ призводило до дезагрегації клітин, а подальше зниження температуря до $16{ }^{\circ} \mathrm{C}$ - до запуску процесу агрегаціі. Отримані результати свідчать про те, що манозослецифічні міжклітинні контакти тимоцктів щурів за участю конқанаваліну А і бактеріальнях клітин внявляють різну чутливість до діі температурн. 


\section{REFERENCES}

1. Bradley B. K., Swiedler S. J., Robbins P. W. Carbohydrate ligands of the LEC cell adhesion molecules // Cell-_ 1990.-63. . P. 861-863.

2. Gabius $H,-J$. Detection and functions of mammalian lectins with emphasis on membrane lectins // Biochim. et biophys. acta, - I991. - 1071, N 1.-P. 1-18.

3. Cowart R. E., Lashmet $J$, McIntosh M. E., Adams T. J. Adherence of virulent strain of Listeria monocytogenes to the surface of hepatocarcinoma cell line via lectin-substrate interaction // Arch. Microbiol.- 1990.-153, N 3.- P. 282-286.

4. Mangan D. F., Norak M. J., Vora S. A. et al. Lectinlike interactions of Fusobacterium nucleatum with human neutrophils // Infect. Immunol-1989.-57, $\mathrm{N}$ il... P. $3601-3611$.

5. Sharon N. Bacherial lectins, cell-cell recognition and iniectious disease//FEBS Lett. - 1987.-217. - P. 145-149.

6. Boner G., Mhashitkar A. M., Rodriguez-Ortega M., Sharon N. Lectin-mediated, unonopsonic phagocytosis of type 1 Escherichia coli by human peritoneal macrophages of uremic patients treated by peritoneal dialysis//J. Leukocytye Biol._ 1989._46.P. $239-245$.

7. Тимоменко А. В., Гсрасимова Л. К., Колупаева Л. Н., Черенкевин С. Н. Межклеточная агрегция тимоцитов и бактериальных клеток Escherichia coli// Биополимеры и клстка.- I991.- 7. № 3.- C. 98-102.

8. Inbar M., Ben-Bassat H., Sachs $I$. Temperature-sensitive activity on the surface mentranc in the activation of lymphocyles by lectins//Exp. Cell Res.- 1973._-76, N $1 . .$. P. $143 \ldots 151$.

9. Rendi $R$, Gordon $I$. A. The effect of temperature on the agglutinability by lectins of liposomes prepared from total lipids of erythrocytes// Ibid.-1977.-110.P. $263-266$.

10. Методы общей бактериологии/Под рсд. Ф. Герхарда и др.-М.:Мнр, 1984.T. $1, \ldots 267 \mathrm{c}$.

11. Gander R. M., Thomas V. L., Forland M. Mannose-resistant hemagglutination and $P$ receptor recognition of uropathogenic Escherichia coli isolated from adull patients // J. Inlect. Diseases, - 1985-151.- P. 508-513.

12. Korkonen T. K., Valtonen $M$. V., Parkkinen $J$. et al. Serotype, hemolysin prodiution, and receptor recognitions of Escherichia coli strains associated with neonatal sepsis and meningit is // Infect. Immunol.- 1985.-48.-P. 486-49].

13. Самаль A. E., Хмара $H . \Phi$. Уеренкевич C. Н. Агрегация тромбоцитов: методы ізучения и механизмы- Минск : Университетское изд-ние, 1990.- $104 \mathrm{c}$.

14. Goetz M. B., Silverblatt F.J. Stimulation of human polymorphonuclear leukocyte oxidative metabolism by type 1 pili from Escherichia coli // Infect. Imınunol. - 1987.— 55, N 3.-P. 534-540.

15. Goldberg S., Doyle R. J., Rosenberg M. Mechanism of enhancement of microbial cell hydrophobicity by cationic polymers // J. Bacteriol-1990.-172.- P. 5650-5654.

Belarusian State University, Minsk

10.09 .93 